\title{
Correlation of Body Composition Analysis with Anthropometric Measurements in Peritoneal Dialysis Patients
}

\section{Periton Diyalizi Hastalarında Vücut Kompozisyonu Analizi ile Antropometrik Ölçümlerin Korelasyonu}

(D) Ayşe Serra ARTAN1, id Meltem GÜRSU1, iD Ömer Celal ELÇíOĞLU1, id Ayşegül YABACI², id Rümeyza KAZANCIOĞLU1

${ }^{1}$ Bezmialem Vakıf University Faculty of Medicine, Department of Nephrology, İstanbul, Turkey

${ }^{2}$ Bezmialem Vakıf University Faculty of Medicine, Department of Biostatistics, İstanbul, Turkey

\section{ABSTRACT}

Objective: This study investigates correlations between different methods for diagnosis of protein energy malnutrition (PEM) in peritoneal dialysis patients.

Methods: Twenty four patients were included. Patients with amputations, infections, peritonitis, malignancies and PD duration less than three months were excluded. Physical examination findings, laboratory results and anthropometric measurements were recorded. Body composition analysis was performed with multi-frequency bioimpedance analyzer. Dialysis malnutrition score (DMS) was calculated. The correlations of different parameters were searched.

Results: Eleven patients were female and 13 patients were male. Mean age was $58.9 \pm 12.6$ years. Median dialysis duration was 25 (interquartile range: 14$)$ months. Protein percentage was negatively correlated with fat percentage $(\mathrm{r}=-0.785 ; \mathrm{p}<0.001)$, triceps skinfold thickness (SFT) $(\mathrm{r}=-0.641 ; \mathrm{p}<0.001)$, biceps SFT $(\mathrm{r}=-$ $0.685 ; \mathrm{p}<0.001)$, body mass index (BMI) $(\mathrm{r}=-0.867 ; \mathrm{p}<0.001)$, mid-arm circumference $(r=-0.680 ; p=0.001)$. Fat percentage was positively correlated with BMI $(r=0.780 ; \mathrm{p}<0.001)$, biceps SFT $(\mathrm{r}=0.817 ; \mathrm{p}<0.001)$, triceps SFT $(\mathrm{r}=0.901 ; \mathrm{p}<0.001)$ and mid-arm circumference $(r=0.558 ; p=0.005)$

Albumin was negatively correlated with DMS ( $r=-0.439 ; \mathrm{p}=0.032)$. DMS and albumin were not correlated with bioimpedance and anthropometry.

Conclusion: Albumin is a marker of PEM in PD patients. Malnutrition scores may be used as adjunct methods. Increase

\section{ÖZ}

Amaç: Çalışmada, periton diyalizi (PD) hastalarında protein enerji malnütrisyonu değerlendirmesinde kullanılan yöntemlerin birbiriyle korelasyonunun araştırılması amaçlandı.

Yöntemler: Çalışmaya 24 hasta alındı. Ekstremite ampütasyonu, enfeksiyon, peritonit, aktif malignite ve PD süresinin üç aydan kısa olması dışlanma kriteri sayıldı. Fizik muayene bulguları, laboratuvar verileri ve antropometrik ölçümler kaydedildi. Multi-frekans biyoempendans ile vücut kompoziyon analizi yapıldı. Diyaliz malnütrisyon skoru (DMS) hesaplandı. Farklı parametrelerin birbirleriyle korelasyonu incelendi.

Bulgular: Hastaların 11'i kadın, 13'ü erkekti. Ortalama yaş $58,9 \pm 12,6$ yıl, ortanca diyaliz süresi ise 25 (çeyreklerarası aralık: $14)$ aydı. Protein oranı; yağ oranı $(\mathrm{r}=-0,785 ; \mathrm{p}<0,001)$, triseps deri katman kalınlığı (DKK) $(\mathrm{r}=-0,641 ; \mathrm{p}<0,001)$, biseps DKK ( $\mathrm{r}=$ $-0,685 ; \mathrm{p}<0,001)$, vücut kitle indeksi (VKI) $(\mathrm{r}=-0,867 ; \mathrm{p}<0,001)$ ve orta kol çevresi $(\mathrm{r}=-0,680 ; \mathrm{p}<0,001)$ ile negatif koreleydi. Yağ oranı; biseps DKK $(r=0,817 ; \mathrm{p}<0,001)$, VKİ $(r=0,780 ; \mathrm{p}<0,001)$, triseps DKK $(r=0,901 ; p<0,001)$ ve orta kol çevresi $(r=0,558 ; p=0,005)$ ile pozitif koreleydi. Albümin, DMS ( $r=-0,439 ; \mathrm{p}=0,032)$ ile negatif korele bulundu. DMS ve albümin düzeyinin biyoempedans tekniği ve antropometrik ölçümler ile anlamlı bir korelasyonu saptanmadı.

Sonuç: Albümin periton diyaliz hastalarında malnütrisyon göstergesidir. Malnütrisyon testleri, serum albümin düzeyine ek yardımcı yöntem olarak kullanılabilir. Periton diyaliz hastalarında yağ kitlesi ve yağ oranının artışı antropometrik ölçümlerin yorumunu etkileyebilir.

Address for Correspondence: Ayşe Serra ARTAN, Bezmialem Vakıf University Faculty of Medicine, Department of Nephrology, istanbul, Turkey

E-mail: ayseserra@gmail.com ORCID ID: orcid.org/0000-0002-6461-3178

Received: 07.07.2020

Cite this article as: Artan AS, Gürsu M, Elçioğlu ÖC, Yabacı A, Kazancıoğlu R. Correlation of Body Composition Analysis with Anthropometric Measurements in Peritoneal Dialysis Patients.

Bezmialem Science 2022;10(1):3-9 
in fat mass and percentage may influence the interpretation of anthropometric measurements.

Keywords: Anthropometric measurements, dialysis malnutrition score, multi-frequency bioimpedance analysis, peritoneal dialysis, protein energy malnutrition, serum albumin
Anahtar Sözcükler: Antropometrik ölçümler, diyaliz malnütrisyon skoru, multi-frekans biyoimpedans analizi, periton diyalizi, protein enerji malnütrisyonu, serum albümin

\section{Introduction}

Protein energy malnutrition (PEM) is a common complication in dialysis patients. Malnutrition is associated with deterioration in quality of life, increased morbidity, cardiovascular and infection-related mortality and total mortality (1). According to one view, underlying comorbidities and inflammatory processes are responsible for both malnutrition and increased morbidity and mortality (2). According to another view, inflammation and malnutrition are independently associated with cardiovascular and all-cause mortality (3). According to the International Society of Renal Nutrition and Metabolism, diagnostic criteria for PEM are as follows: Biochemically; low serum albumin $(<3.8 \mathrm{~g} / \mathrm{dL})$ or prealbumin $(<30 \mathrm{mg} / \mathrm{dL})$ or total cholesterol $(<100 \mathrm{mg} / \mathrm{dL})$, in terms of body mass; low body mass index (BMI) $\left(<23 \mathrm{~kg} / \mathrm{m}^{2}\right)$ or decreased body fat $(<10 \%)$ or unintended weight loss (more than $5 \%$ in 3 months), in terms of muscle mass; reduction in muscle mass (more than $5 \%$ at 3 months) or lower middle arm muscle circumference or reduction in protein equivalent of nitrogen appearance (PNA); in terms of dietary intake; involuntary insufficient protein or energy intake. PEM is diagnosed with the presence of at least 3 of these criteria (4).

According to the latest data, the frequency of PEM varies between $28 \%$ and $60 \%$ in hemodialysis and peritoneal dialysis (PD) patients (1). Malnutrition may develop due to many factors in patients with end-stage renal disease. Among the identified causes are; loss of appetite due to uremia, decrease in dietary calorie intake, dietary restrictions, chronic inflammation, proteinuria, other comorbid diseases, and the dialysis process itself, which causes loss of amino acids and proteins (5).

Due to its clinical importance, malnutrition should be carefully monitored. With early diagnosis, progression of malnutrition and muscle wasting are prevented. Many methods are used for clinical diagnosis. Among them; clinical evaluation, weight monitoring, biochemical tests (serum albumin, prealbumin, creatinine and lipid levels), and anthropometric measurements can be counted in the first stage (6). There are also various questionnaires evaluating malnutrition. Among them, subjective global assessment (SGA), malnutrition inflammation score (MIS), dialysis malnutrition score (DMS) also called modified-SGA(m-SGA) score, and mini-nutritional assessment (MNA) (7). Dual energy X-ray absorptiometry and multifrequency bioelectrical impedance analysis are also among the available. methods that can be used for diagnostic purposes (5). None of these methods is sufficient alone in the detection of malnutrition. The methods have been used in various combinations.
In our clinic, monthly albumin and C-reactive protein (CRP) measurements and anthropometric measurements are performed every six months in the malnutrition evaluation of PD patients. Patients' complaints such as loss of appetite and weight loss are taken into account in this evaluation.

In this study, we aimed to investigate which methods gave more accurate results in the cross-sectional evaluation of malnutrition in PD patients. We applied anthropometric measurements, bioimpedance analysis, biochemical parameters and DMS test together in our patients and investigated the relationship between the methods.

\section{Method}

Our study was approved by the ethics committee of our university (ethics committee file number: 22/420), and the principles stated in the Declaration of Helsinki were complied with. Written and verbal consent was obtained from all patients.

Patient Selection: The study included 24 patients followed up in the PD outpatient clinic, either in the automated PD or continuous ambulatory $\mathrm{PD}$ program. Patients who refused to give written consent, patients with limb amputation, active infection, peritonitis or active malignancy, and patients with dialysis duration shorter than three months were excluded. Patients with cured malignancy or in remission in terms of malignancy were included in the study.

Study Parameters: Demographic and physical examination findings: Age, gender, duration of dialysis, primary kidney disease and comorbidities of all patients were recorded. Physical examinations were performed, systolic and diastolic blood pressures were recorded, and the presence of edema was evaluated.

Laboratory parameters: Daily urine amount (mL/day), proteinuria amount $(\mathrm{mg} /$ day), albumin $(\mathrm{g} / \mathrm{dL})$ and CRP $(\mathrm{mg} / \mathrm{L})$ levels were measured. The $\mathrm{kt} / \mathrm{V}$ value as an indicator of dialysis adequacy, and normalized protein catabolic rate (nPCR) were recorded as an indicator of protein catabolism.

Anthropometric Measurements: All anthropometric measurements were made by the same investigator from the nondominant side and repeated twice. Mid-arm circumference was measured with a tape measure, and triceps and biceps skinfold thicknesses (SFT) were measured using a "skinfold caliper".

DMS or m-SGA: The m-SGA scores of all patients were calculated using the form developed by Kalantar-Zadeh $(8,9)$. In this scoring system, which is developed based on the SGA test, 7 criteria are evaluated with scores ranging from 1 to 5 . 
These criteria are weight loss, dietary intake, gastrointestinal symptoms, functional capacity, decreased fat stores on physical examination or signs of decreased subcutaneous fat and muscle wasting in the last six months. One point is considered normal and five points are considered severe malnutrition. Final scoring is done with the sum of the 7 components. The score obtained varies between 7-35. Seven points represent normal nutritional status and 35 points represent severe malnutrition $(8,9)$.

Body Composition Analysis: Body composition analysis was performed with the TANITA MC 780 (Tanita Corporation, Tokyo, Japan). This technique performs bioimpedance analysis using 6 frequency currents (multi-frequency BIA-MF BIA). Basal metabolic rate, total body water and percentage (\%), fat mass, fat percentage, muscle mass, muscle percentage, bone mass, protein percentage were measured and recorded.

\section{Statistical Analysis}

The distribution of the data was analyzed with the Shapiro-Wilk test. The relationship between numerical variables was examined by Spearman Correlation analysis. Descriptive statistics of the data were given as $\mathrm{n}(\%)$ for categorical variables, and as median (interquartile range) for non-normally distributed numerical variables. All statistical analyzes were analyzed and reported at the $\alpha=0.05$ significance level in the IBM SPSS Statistics 22.0 program.

\section{Results}

Twenty-four patients were included in the study, of whom 11 were female and 13 were male. The mean age was 58.9 \pm 12.6 years, and the median dialysis time was 25 months (interquartile range: 14 ).

Primary kidney disease was diabetic nephropathy in 5 (20.8\%) patients, autosomal dominant polycystic kidney disease in 3 (12.5\%) patients, chronic glomerulonephritis in $3(12.5 \%)$ patients, and nephrosclerosis in $2(8.3 \%)$ patients. Urological causes were present in $1(4.2 \%)$ patient and the etiology was unknown in $10(41.7 \%)$ patients.

Of the patients, 21 (87.5\%) had hypertension, $9(37.5 \%)$ diabetes mellitus, 7 (29.2\%) hyperlipidemia, 7 (29.2\%) coronary artery disease, and 4 (16.7\%) had a history of malignancy. Two patients had untreated prostate cancer, 1 patient had cured laryngeal cancer, and 1 patient had breast cancer in remission with ongoing hormonal therapy. There was no patient with metastatic malignancy.

The median systolic and diastolic blood pressures were 120 mmHg (IRQ: 28) and $80 \mathrm{mmHg}$ (IRQ: 28), respectively. While 8 patients were using one type of antihypertensive drug, 9 patients were using 2 drugs, and 5 patients were using 3 drugs. Two patients did not need antihypertensive medication. Edema was detected in 6 patients.

Demographic and clinical characteristics, physical examination findings, and laboratory tests of the patients are summarized in Table 1 .
The median albumin level was 3.6 (IRQ: 0.5 ) g/dL, it was $\leq 3.5$ $\mathrm{g} / \mathrm{dL}$ in 7 (29.2\%) patients, 3.6-4 in $14 \mathrm{~g} / \mathrm{dL}(58.3 \%)$ patients, and $>4 \mathrm{~g} / \mathrm{dL}$ in $3(12.5 \%)$ patients. The median CRP level was $3.25 \mathrm{mg} / \mathrm{L}$ (IRQ: 7.63) and was above the reference values in 9 patients. The median urine volume was $905 \mathrm{~mL} /$ day (IRQ: 646), and the median proteinuria was $327.88 \mathrm{mg} /$ day (IRQ: 944.88). The median weekly creatinine clearance, median kt/V, and median nPCR were $67.46 \mathrm{~mL} / \mathrm{min}$ (AUC: 25.82), 2 (IRQ: 0.66 ) and $0.76 \mathrm{~g} / \mathrm{kg} /$ day (IRQ: 0.29 ), respectively.

The median BMI was $28.30 \mathrm{~kg} / \mathrm{m} 2$ (IRQ: 9.25). The median middle arm circumference was $28.50 \mathrm{~cm}$ (IRQ: 6.75). Median

Table 1. Demographic, clinical characteristics and physical examination and laboratory findings of the patients *given as median and interquartile range

\begin{tabular}{|c|c|}
\hline & $\begin{array}{l}\text { Patients } \\
\mathrm{n}=24\end{array}$ \\
\hline $\begin{array}{l}\text { Age (mean, standard } \\
\text { deviation) }\end{array}$ & $58.9 \pm 12.6$ \\
\hline Gender (female) & $11 / 24$ \\
\hline Dialysis time* & $25(14)$ \\
\hline & $\begin{array}{l}20.8 \% \text { diabetic nephropathy, } \\
12.5 \% \text { autosomal dominant } \\
\text { polycystic kidney disease, }\end{array}$ \\
\hline $\begin{array}{l}\text { Etiology of chronic kidney } \\
\text { disease (\%) }\end{array}$ & $\begin{array}{l}12.5 \% \text { chronic glomerulonephritis, } \\
8.3 \% \text { nephrosclerosis, } \\
4.2 \% \text { urological causes, } \\
41.7 \% \text { unknown etiology, }\end{array}$ \\
\hline Hypertension (\%) & 87.5 \\
\hline Diabetes mellitus (\%) & 29.2 \\
\hline Coronary artery disease (\%) & 29.2 \\
\hline Malignancy (\%) & 16.7 \\
\hline $\begin{array}{l}\text { Systolic blood pressure* } \\
(\mathrm{mmHg})\end{array}$ & $120(28)$ \\
\hline $\begin{array}{l}\text { Diastolic blood pressure* } \\
(\mathrm{mmHg})\end{array}$ & $80(10)$ \\
\hline Edema (\%) & 25 \\
\hline Albumin* $(\mathrm{g} / \mathrm{dL})$ & $3.60(0.50)$ \\
\hline $\mathrm{CRP}^{*}$ (mg/L) & $3.25(7.63)$ \\
\hline Urine volume* (mL/day) & 905 (646) \\
\hline Proteinuria* (mg/day) & $327.88(944.88)$ \\
\hline $\begin{array}{l}\text { Creatinine clearance* (mL/ } \\
\text { min) }\end{array}$ & $67.46(25.82)$ \\
\hline $\mathrm{Kt} / \mathrm{V}^{*}$ & $2(0.66)$ \\
\hline$n P C R^{*}(g / k g / d a y)$ & $0.76(0,29) \mathrm{g} / \mathrm{kg} /$ day \\
\hline Body mass index* $\left(\mathrm{kg} / \mathrm{m}^{2}\right)$ & $28.30(9.25)$ \\
\hline
\end{tabular}


biceps and triceps SFTs were measured as $10 \mathrm{~mm}$ (IRQ: 12.25) and $16 \mathrm{~mm}$ (IRQ: 18.50), respectively. The median DMS score was 11 (IRQ: 4.75); while it was normal in $16(66.7 \%)$ patients, it was compatible with moderate malnutrition in 8 (33.3\%) patients.

Body composition analysis results are presented in Table 2.

Correlation Analysis Results: Muscle mass was positively correlated with bone mass $(\mathrm{r}=0.970 ; \mathrm{p}<0.001)$ and fluid percentage $(r=0.514 ; \mathrm{p}=<0.010)$; and it was negatively correlated with fat percentage $(\mathrm{r}=-0.462 ; \mathrm{p}=0.023)$ and $\mathrm{Kt} / \mathrm{V}(\mathrm{r}=-0.612$; $\mathrm{p}=0.001)$.

Protein percentage was positively correlated with fluid percentage $(r=0.681 ; p<0.001)$, and it was negatively correlated with fat percentage $(\mathrm{r}=-0.785 ; \mathrm{p}<0.001)$, fat mass $(\mathrm{r}=-0.833$; $\mathrm{p}<0.001)$, triceps SFT $(\mathrm{r}=-0.641 ; \mathrm{p}<0.001)$, biceps SFT $(\mathrm{r}=-$ $0.685 ; \mathrm{p}<0.001)$, BMI $(\mathrm{r}=-0.867 ; \mathrm{p}<0.001)$, and middle arm circumference $(r=-0.680 ; p=0.001)$.

Fat content was negatively correlated with fluid percentage ( $\mathrm{r}=-$ $0.867 ; \mathrm{p}<0.001)$, and it was positively correlated with protein percentage $(\mathrm{r}=-0.833 ; \mathrm{p}<0.001)$; BMI $(\mathrm{r}=0.940 ; \mathrm{p}<0.001)$, biceps SFT $(r=0.874 ; p<0.001)$, triceps SFT $(r=0.855 ; p<0.001)$, and middle arm circumference $(r=0.705 ; \mathrm{p}<0.001)$.

Fat percentage was negatively correlated with fluid percentage $(\mathrm{r}=-0.977 ; \mathrm{p}<0.001)$, and it was positively correlated with BMI $(\mathrm{r}=0.780 ; \mathrm{p}<0.001)$, biceps SFT $(\mathrm{r}=0.817 ; \mathrm{p}<0.001)$, triceps SFT $(r=0.901 ; \mathrm{p}<0.001)$ and mid-arm circumference $(r=0.558$; $\mathrm{p}=0.005)$.

Albumin level was positively correlated with creatinine clearance $(\mathrm{r}=0.561 ; \mathrm{p}=0.004)$ and urine volume $(\mathrm{r}=0.566 ; \mathrm{p}=0.004)$, and it negatively correlated with age $(\mathrm{r}=-0.464 ; \mathrm{p}=0.022)$ and DMS score $(\mathrm{r}=-0.439 ; \mathrm{p}=0.032)$.

Table 2. Bioimpedance analysis results Mean \pm standard deviation

\begin{tabular}{l|l}
\hline Bone mass $(\mathrm{kg})$ & $2.78 \pm 0.40$ \\
\hline Fat mass $(\mathrm{kg})$ & $22.94 \pm 9.77$ \\
Fat percentage $(\%)$ & $28.86 \pm 9.43$ \\
Liquid amount $(\mathrm{kg})$ & $38.93 \pm 6.78$ \\
Liquid percentage $(\%)$ & $50.38 \pm 6.71$ \\
Muscle mass $(\mathrm{kg})$ & $52.12 \pm 8.55$ \\
Protein percentage $(\%)$ & $16.16 \pm 2.70$
\end{tabular}

The nPCR level was positively correlated with $\mathrm{kt} / \mathrm{V}$ ( $\mathrm{r}=0.617$; $\mathrm{p}=0.001)$ and proteinuria $(\mathrm{r}=0.494 ; \mathrm{p}=0.014)$. The relationship between classification according to albumin level and nutritional assessment according to DMS is presented in Table 3.

There was no significant correlation of DMS with bioimpedance technique and anthropometric measurements. There was no significant correlation of albumin level with bioimpedance technique and anthropometric measurements.

\section{Discussion}

Malnutrition is an important complication of end-stage renal disease (ESRD) and a marker of mortality. Detection of weight loss, anthropometric measurements, evaluation of biochemical markers such as serum albumin and prealbumin level are used in the diagnosis (6). In our study, a negative correlation was found between DMS and albumin level. DMS and albumin levels were not associated with body composition analysis and anthropometric measurements. SFT and middle arm circumference were found to be associated with the amount and percentage of fat, and they were found to be negatively correlated with the protein percentage.

It has been shown that albumin level is a strong marker of malnutrition in patients with ESRD (10). However, there are some limitations in clinical use. Since albumin is also a negative acute phase protein, it is decreased in inflammatory states. In addition, it is affected by many factors such as its loss in urine and dialysate, and its decreased synthesis, and these factors reduce the power of albumin level in the assessment of malnutrition $(4,11)$.

The mean albumin level of our patients was found to be $3.62 \pm 0.33$ $\mathrm{g} / \mathrm{dL}$. In our study, a negative correlation was found between DMS and albumin level $(r=-0.439 ; p=0.032)$. The patients with normal albümin level also had normal nutritional status when evaluated according to the DMS. It can be interpreted that the albumin level and DMS are in parallel.

The median CRP level was found to be $3.25 \mathrm{mg} / \mathrm{L}$ (IRQ: 7.63). Since the CRP level was within normal limits in $62.5 \%$ of the patients and patients with acute infection or active malignancy were excluded, it was thought that serum albumin level was less affected by the inflammatory state in our study and gave a sufficient result in reflecting malnutrition in this respect.

DMS is an adaptation of the SGA developed by Kalantar-Zadeh in 1999. In a study conducted with 41 patients, it was found that DMS showed statistically significant negative correlation

Table 3. Relationship between albumin levels and nutritional status assessed by dialysis malnutrition score

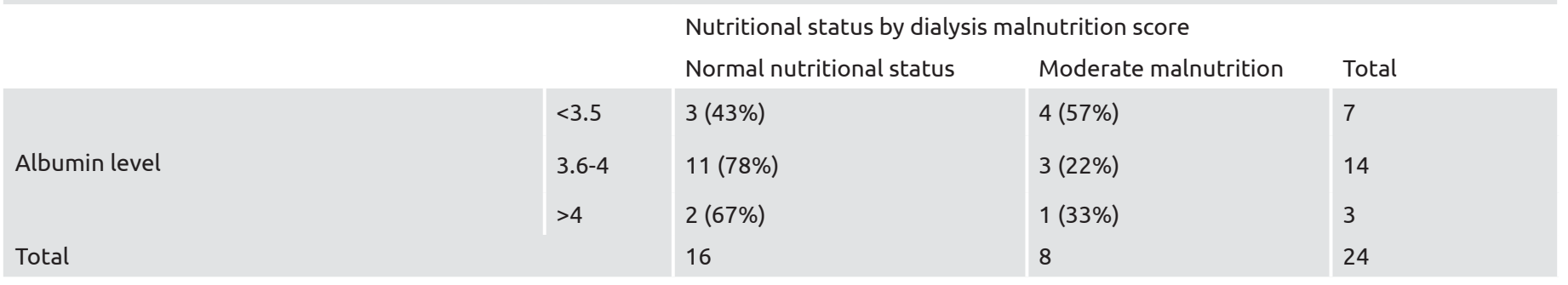


with mid-arm circumference, mid-arm area, BMI, biceps SFT, serum albumin, and total protein (9). In later studies, it has been shown that the DMS is associated with anthropometric measurements and serum albumin level in the detection of malnutrition $(12,13)$. In our study, DMS was used because of its simplicity, ease of application and fast application. The negative correlation between DMS and albümin in our study was found to be compatible with other studies using DMS $(9,12,13)$.

There are several studies showing a strong association of not only DMS but also various other nutritional tests with serum albumin level, which is consistent with the results of our study. In a study conducted by Visser et al. in 1999, SGA was found to be associated with albumin, BMI, mid-arm circumference and fat percentage in 22 hemodialysis and PD patients (14). In a study conducted by Sezer et al. with 100 PD patients, similar to our study, it was found that serum albumin levels were found to be significantly lower in patients who were determined to be malnourished according to the SGA (15).

Anthropometric measurements are inexpensive and relatively easy tests that have been applied for many years. Studies to standardize these measurements are limited. Since measurements take a long time to change, they are insufficient to show the effects of short-term nutritional interventions on patients (16). In one study, patients were separated according to albumin level and SGA score. While anthropometric measurements were found to be related with SGA score in patients with PEM; no correlation was found between anthropometric measurements and low albumin level in these patients (17). In our study, DMS and albumin were not associated with body composition analysis and anthropometric measurements.

Bioimpedance analysis is a fast, non-invasive and safe technique. Its advantages are that it is independent of the user and provides information about the patient's hydration status. The negative aspect is that it is not available in every center.

According to the study of Passadakis et al. (18) on 47 PD patients, the phase angle was found to be compatible with the results of the SGA. In another study performed in the pediatric age group, it was reported that findings of bioimpedance analysis were correlated with nutritional assessment according to SGA and that findings of bioimpedance analysis were found to be associated with survival $(19,20)$.

In our study, no correlation was found between bioimpedance methods and albumin, DMS and anthropometric measurements.

In the publication of Oe et al. (21), SFT and bioimpedance analysis were compared in 4 areas before and after dialysis in hemodialysis patients. Lean body mass and body fat mass were evaluated. The two techniques were correlated with each other in determining body fat and lean body mass. In another study, 100 hemodialysis patients were evaluated according to MNA, bioimpedance and biochemical parameters, and the reliability of bioimpedance analysis in terms of diagnosis of malnutrition was investigated. According to this study, albumin level was found to be higher in the group without malnutrition but at risk of malnutrition than in the group with malnutrition. Fat percentage, fat mass, muscle mass and lean body mass were found to be significantly higher in the non-malnutrition group than in the malnourished and risky group, and it was concluded that bioimpedance analysis could be used in the diagnosis (22). In our study, the patients were classified according to their DMS and albumin levels, and the anthropometric measurements of these subgroups were compared. No significant difference was found. Compared to the other studies mentioned, the higher BMI of our patients and the low number of patients whose malnutrition was detected by other methods could be counted among the reasons for the difference in our findings.

In PD patients, weight change may not be correlated with lean body mass. In the study of Schmidt et al. in which they followed up PD patients, weight loss was found in only 36\% of the patients, and $49 \%$ had a reduction in lean body mass (23). A decrease in lean body mass was found in 24\% of 64 patients whose weight was found to be increased. In another study, it was reported that there was a significant increase in BMI, body fat mass and body fat mass and a significant decrease in lean body mass in PD patients (24). Mid-arm circumference was found to be a moderately reliable indicator of lean mass and amount of adipose tissue $(25,26)$. Again, in a one-year follow-up study conducted in PD patients, BMI was found to be significantly associated with mid-arm circumference, biceps SFT, and visceral and subcutaneous fat detected by abdominal tomography in the initial evaluation. In one-year follow-up, it was found that the amount of visceral and subcutaneous fat and biceps SFT increased significantly (27). This study is similar to the findings of our study in terms of the relationship between anthropometry and fat percentage. In our study, SFT and mid-arm circumference were found to be significantly associated with the amount of fat, and a strong negative correlation was found between SFT and mid-arm circumference, and the amount of protein. This may be associated with the possibility of altered tissue distribution in PD patients. Possible reasons for this change are continuous glucose absorption from dialysate, increase in body fat percentage and protein malnutrition due to protein loss from dialysate $(28,29)$. It was thought that anthropometric measurements in PD patients could not be interpreted similarly to healthy adults, and biceps SFT and mid-arm circumferences, which reflected both subcutaneous fat and lean body mass, showed more fat percentage in PD patients.

The relationship between malnutrition indicators and clinical outcome in geriatric hemodialysis patients was investigated. SGA, low serum albumin level, MIS and hand grip strength were found to be associated with hospitalization; and SGA, MIS, calf circumference and BMI were found to be associated with mortality (30). No relationship was found between the midarm circumference and triceps SFT, which were also used in our study, with hospitalization and mortality. As seen in that study example, serum albumin level and malnutrition tests are more effective methods in estimating clinical outcomes than mid-arm circumference and SFT. 
In conclusion, several nutritional diagnostic methods used in the clinic were evaluated together in our study. Serum albumin and nutritional tests have a definite place in the diagnosis of malnutrition, as shown in many other studies. Anthropometric measurements and bioimpedance analysis are routine tests based on healthy people. According to the results of our study, the interpretation of these tests in PD patients should be done carefully. However, considering the strong correlation between anthropometry and bioimpedance analysis in terms of fat mass, we think that it can be included in the malnutrition assessment routine.

\section{Study Limitations}

The main limitations of our study were the small number of patients and its cross-sectional nature.

\section{Conclusion}

Albumin is an indicator of malnutrition in PD patients. Examination and laboratory data remain valuable in nutritional assessment. Malnutrition tests (DMS) can be used as an auxiliary method in addition to serum albumin level in PD patients in the examination of malnutrition. Evaluation of body composition and anthropometric measurements may not be informative enough cross-sectionally. Serial assessments can be stimulus for detecting malnutrition.

\section{Ethics}

Ethics Committee Approval: Our study was approved by the ethics committee of our university (ethics committee file number: 22/420), and the principles stated in the Declaration of Helsinki were complied with.

Informed Consent: Written and verbal consent was obtained from all patients.

Peer-review: Externally peer reviewed.

\section{Authorship Contributions}

Surgical and Medical Practices: A.S.A., Concept: A.S.A., M.G., R.G., Design: M.G., A.Y., R.K., Data Collection or Processing: A.S.A., M.G., Ö.C.E., A.Y., Analysis or Interpretation: A.S.A., Ö.C.E., A.Y., Literature Search: A.S.A., Ö.C.E., Writing: A.S.A., M.G., R.K.

Conflict of Interest: No conflict of interest was declared by the authors.

Financial Disclosure: The authors declared that this study received no financial support.

\section{References}

1. Lodebo BT, Shah A, Kopple JD. Is it Important to Prevent and Treat Protein-Energy Wasting in Chronic Kidney Disease and Chronic Dialysis Patients?J Ren Nutr 2018;28:369-79.

2. Stenvinkel P, Heimbürger O, Lindholm B, Kaysen GA, Bergström J. Are there two types of malnutrition in chronic renal failure? Evidence for relationships between malnutrition, inflammation and atherosclerosis (MIA syndrome) Nephrol Dial Transplant 2000;15:953-60.

3. Ishii H, Takahashi H, Ito Y, Aoyama T, Kamoi D, Sakakibara T, et al. The Association of Ankle Brachial Index, Protein-Energy Wasting, and Inflammation Status with Cardiovascular Mortality in Patients on Chronic Hemodialysis. Nutrients 2017;9:416.

4. Fouque D, Kalantar-Zadeh K, Kopple J, Cano N, Chauveau P, Cuppari L, et al.Proposed nomenclature and diagnostic criteria for protein-energy wasting in acute and chronic kidney disease. Kidney Int 2008;73:391-8.

5. Locatelli F, Fouque D, Heimburger O, Drüeke TB, CannataAndía JB, Hörl WH, et al. Nutritional status in dialysis patients: a European consensus. Nephrol Dial Transplant 2002;17:563-72.

6. National Kidney Foundation. Clinical practice guidelines for nutrition in chronic renal failure. Am J Kidney Dis 2000;35:Suppl 2:56-64.

7. Tsai AC, Wang JY, Chang TL, Li TY. A comparison of the full mini nutritional assessment, short-form mini nutritional assessment, and subjective global assessment to predict the risk of protein-energy malnutrition in patients on peritoneal dialysis: a cross-sectional study. Int J Nurs Stud 2013;50:83-9.

8. Streiber AL, Kalantar-Zadeh K, Secker D, McCarthy M, Sehgal A, McCann L. Subjective global assessment in chronic kidney disease: a review. J Ren Nutr 2004;14:191-200.

9. Kalantar-Zadeh K, Kleiner M, Dunne E, Lee GH, Luft FC. A modified quantitative subjective global assessment of nutrition for dialysis patients. Nephrol Dial Transplant 1999;14:1732-8.

10. Rocco MV, Jordan JR, Burkart JM. The efficacy number as a predictor of morbidity and mortality in peritoneal dialysis patients. J Am Soc Nephrol 1993;4:1184-91.

11. Yeun JY, Kaysen GA. Factors influencing serum albumin in dialysis patients. Am J Kidney Dis 1998;32:118-25.

12. Kalantar-Zadeh K, Kopple JD, Block G, Humphreys MH. A malnutrition-inflammation score is correlated with morbidity and mortality in maintenance hemodialysis patients. Am J Kidney Dis 2001;38:1251-63.

13. Janardhan V, Soundararajan P, Rani NV, Kannan G, Thennarasu P, Chacko RA, et al. Prediction of malnutrition using modified subjective global assessment-dialysis malnutrition score in patients on hemodialysis. Indian J Pharm Sci 2011;73:38-45.

14. Visser R, Dekker FW, Boeschoten EW, Stevens P, Krediet RT. Reliability of the 7-point subjective global assessment scale in assessing nutritional status of dialysis patients. Adv Perit Dial 1999; 15:222-5.

15. Sezer S, Ozdemir FN, Akman B, Arat Z, Anaforoglu I, Haberal M. Predictors of serum albumin level in patients receiving continuous ambulatory peritoneal dialysis. Adv Perit Dial 2001;17:210-4.

16. Afşar B, Elsürer R, Sezer S. Son Dönem Böbrek Yetmezliği Hastalarının Nütrisyonel Durumlarının Değerlendirmesinde Kullanılan Yöntemler. Turkiye Klinikleri J Nephrol 2008;3:71-7.

17. Jones CH, Newstead CG, Will EJ, Smye SW, Davison AM. Assessment of nutritional status in CAPD patients: serum albumin is not a useful measure. Nephrol Dial Transplant 1997;12:1406-13. 
18. Passadakis P, Sud K, Dutta A, Singhal M, Pettit J, Chatalalsingh $\mathrm{C}$, et al. Bioelectrical impedance analysis in the evaluation of the nutritional status of continuous ambulatory peritoneal dialysis patients. Adv Perit Dial 1999;15:147-52.

19. Özçetin M, Khalilova F, Kılıç A. An Uncommon Method of Evaluating Nutritional Status: BIA. Çocuk Dergisi 2017;17:61-6.

20. Mushnick R, Fein PA, Mittman N, Goel N, Chattopadhyay J, Avram MM. Relationship of bioelectrical impedance parameters to nutrition and survival in peritoneal dialysis patients. Kidney Int Suppl 2003;87:S53-6.

21. Oe B, de Fijter CW, Oe PL, Stevens P, de Vries PM. Four-site skinfold anthropometry (FSA) versus body impedance analysis (BIA) in assessing nutritional status of patients on maintenance hemodialysis: which method is to be preferred in routine patient care? Clin Nephrol 1998;49:180-5.

22. Erdoğan E, Tutal E, Uyar ME, Bal Z, Demirci BG, Sayın B, et al. Reliability of bioelectrical impedance analysis in the evaluation of the nutritional status of hemodialysis patients - a comparison with mini nutritional assessment. Transplant Proc 2013;45:3485-8.

23. Schmidt R, Dumler F, Cruz C, Lubkowski T, Kilates C. Improved nutritional follow-up of peritoneal dialysis patients with bioelectrical impedance. Adv Perit Dial 1992;8:157-9.

24. Stenvinkel P, Lindholm B, Lönnqvist F, Katzarski K, Heimbürger $\mathrm{O}$. Increases in serum leptin levels during peritoneal dialysis are associated with inflammation and a decrease in lean body mass. J Am Soc Nephrol 2000;11:1303-9.
25. Klahr S, Levey AS, Beck GJ, Caggiula AW, Hunsicker L, Kusek JW, et al. The effects of dietary protein restriction and blood pressure control on the progression of chronic renal disease. Modification of diet in renal disease study group. N Engl J Med 1994;330:877-84.

26. Eknoyan G, Levey A, Beck GJ, Agodoa LY, Daugirdas JT, Kusek JW, et al. The hemodialysis (HEMO) study:rationalefor selection of interventions. Semin Dial 1996;9:24-33.

27. Choi SJ, Kim NR, Hong SA, Lee WB, Park MY, Kim JK, et al. Changes in body fat mass in patients after starting peritoneal dialysis. Perit Dial Int 2011;31:67-73.

28. Fernström A, Hylander B, Moritz Å, Jacobsson H, Rössner S. Increase of intra-abdominal fat in patients treated with continuous ambulatory peritoneal dialysis. Perit Dial Int 1998;18:166-71.

29. Heimbürger O, Lindholm B, Bergström J. Nutritional effects and management of chronic peritoneal dialysis. In : Kopple JD, Massry $S$, editors. Nutritional Management of Renal Disease. Baltimore, Williams \& Wilkins; 1997. p619-68.

30. Rodrigues J, Santin F, Brito FDSB, Lindholm B, Stenvinkel P, Avesani CM. Nutritional status of older patients on hemodialysis:Which nutritional markers can best predict clinical outcomes? Nutrition 2019;65:113-9. 